\author{
Vol.VII, Issue.2, December, 2019 \\ P-ISSN 2302-3783
}

This work is licensed under a Creative Commons Attribution 4.o International License (cc-by)

\title{
Pemalsuan Akta Autentik Sebagai Aspek Pidana Notaris
}

\author{
M.Jamil \\ Fakultas Syari'ah dan Hukum UIN Sunan Kalijaga, Yogyakarta, Indonesia \\ Email Coresponden: jamilncera@gmail.com
}

\begin{abstract}
The notary is known as a respected official in accordance with the mandate of the law. In Article 1 paragraph 1 of the Amended UUJN, it is stated that a Notary Public is authorized to make an authentic deed and has other authorities as referred to in this Law or based on other laws. Sometimes the labeling of the word "honorable" carried by a notary is injured by irresponsible notaries. many persons who do not think long will be the result of what has been done. The increasing number of notaries and the complexity of the problems faced by a notary public there are also notaries who are entangled with legal cases related to authentic deed forgery. The State of Indonesia is a state of law, in a state of law all people are treated equally before the law, this also applies to the profession of Notary. Notaries can be convicted if they meet the criminal elements contained in Article 263 paragraph (1) and Article 264 paragraph (1) of the Criminal Code. In this study, the author conducted a juridical-normative analysis based on literature study.
\end{abstract}

Keywords: Authentic Deed, Criminal Aspects, Notary Public.

\begin{abstract}
Abstrak
Notaris dikenal sebagai pejabat terhormat sesuai amanah undang-undang. Pada Pasal 1 ayat 1 UUJN Perubahan, disebutkan Notaris adalah pejabat umum yang berwenang untuk membuat akta autentik dan memiliki kewenangan lainnya sebagaimana dimaksud dalam Undang-Undang ini atau berdasarkan undang-undang lainnya. Kadangkala pelabelan "terhormat" yang disandang Notaris di cederai oleh oknum-oknum Notaris yang tidak bertanggungjawab. Oknum tersebut tidak berpikir panjang akan akibat dari apa yang dilakukan. Semakin banyaknya notaris dan semakin kompleksnya persoalan yang dihadapi oleh seorang Notaris maka ada juga Notaris yang bersentuhan dengan kasus hukum terkait pemalsuan akta autentik. Negara Indonesia adalah negara hukum, dalam suatu negara hukum semua orang diperlakukan sama dihadapan hukum (equality before the law), diberlakukan juga pada profesi Notaris. Notaris dapat di pidana ababila memenuhi unsur pidana yang termuat dalam Pasal 263 ayat (1) dan Pasal 264 ayat (1) KUHP. Pada penelitian ini, Penulis melakukan Analisis secara yuridis-normatif berdasarkan studi pustaka.
\end{abstract}

Kata Kunci: Akta Autentik, Aspek Pidana, Notaris.

\section{Pendahuluan}

Konstitusi Indonesia secara tegas menyebutkan bahwasannya Negara Indonesia adalah negara hukum (Lihat Pasal 1 ayat (3) amandemen ketiga UUD 1945). Karena Negara Kesatuan Republik Indonesia (NKRI) menganut Negara hukum, maka dalam suatu negara hukum semua orang harus diperlakukan sama dihadapan hukum (equality before the law). Asas persamaan di muka hukum (equality before the law) tidak secara ekplisit tercantum dalam ketentuan Kitab Undang-Undang Hukum Acara Pidana (KUHAP). Asas ini hanya dicantumkan 
dalam penjelasan resmi KUHAP. Walaupun demikian, merupakan bagian yang tidak terpisahkan dari Kitab Undang-Undang itu sendiri. Asas ini dijabarkan dalam kalimat: "Perlakuan yang sama atas diri setiap orang di muka hukum dengan tidak mengadakan pembedaan perlakuan”. Ditempatkan asas ini sebagai asas kesatu menunjukkan betapa pentingnya asas ini dalam tata kehidupan hukum di Indonesia (Romli Atmasasmita, 2011: 73).

Ramly Hutabarat menjelaskan bahwa teori equality before the law menurut UUD 1945 adalah suatu mata rantai antara hak dan kewajiban yang harus berfungsi menurut kedudukannya masing-masing. Kesamaan di hadapan hukum berarti setiap warga negara harus diperlakukan adil oleh aparat penegak hukum dan pemerintah (Hukum Online, https://www.hukumonline.com, 03/03/2020). Persamaan dihadapan hukum (equality before the law) merupakan Asas yang menjadi salah satu sendi doktrin Rule of Law di negara-negara maju yang kini juga menyebar pada negara-negara berkembang seperti Indonesia, karena Perundang-undangan di Indonesia mengadopsi asas ini sejak masa kolonial melalui Burgelijke Wetboek (KUHPerdata) dan Wetboek van Koophandel voor Indonesie (KUHDagang) pada 30 April 1847 melalui Stb. 1847 No. 23. (Pradipa Yoedhanegara, https://www.obsessionnews.com, 03/03/2020).

Oleh karenanya, setiap orang yang melakukan perbuatan melawan hukum, apapun profesinya, termasuk Notaris, dalam hal ini apabila menyalahi kewenangan dan tanggungjawabnya sebagai pejabat publik yang diamanahkan oleh undang-undang, maka akan menerima konsekwensi hukum atas apa yang ia perbuat. Begitu juga sebaliknya, selama Notaris dalam menjalankan jabatannya, apabila telah dilakukan dengan prosedur yang benar, yakni tidak menyalahi Undang-Undang Nomor 30 Tahun 2004 Tentang Jabatan Notaris (UUJN) yang terakhir disempurnakan dengan Undang-undang Republik Indonesia Nomor 2 Tahun 2014 Tentang Perubahan atas Undang-Undang Nomor 30 Tahun 2004 Tentang Jabatan Notaris (selanjutnya disebut UUJN Perubahan), Anggaran Dasar Notaris, Kode Etik Notaris, serta peraturan perundang-undangan yang berkaitan dengan tugas dan tanggungjawabnya, seharusnya Notaris tidak perlu takut dan gentar apabila berhadapan dengan proses hukum.

Secara umum, Notaris dikenal sebagai pejabat terhormat yang diberi kewenangan oleh undang-undang. Terkait kewenangannya dapat ditemukan dalam rumusan Pasal 15 UUJN Perubahan. Pada Pasal 15 ayat (1) UUJN Perubahan dijelaskan bahwa Notaris berwenang membuat Akta autentik mengenai semua perbuatan, perjanjian, dan penetapan yang diharuskan oleh peraturan perundang-undangan dan/atau yang dikehendaki oleh yang berkepentingan untuk dinyatakan dalam Akta autentik, menjamin kepastian tanggal pembuatan Akta, menyimpan Akta, memberikan grosse, salinan dan kutipan Akta, semuanya itu sepanjang pembuatan Akta itu tidak juga ditugaskan atau dikecualikan kepada pejabat lain atau orang lain yang ditetapkan oleh undang-undang.

Bunyi Pasal 1 ayat (1) UUJN Perubahan, dikatakan bahwasannya Notaris adalah pejabat umum yang berwenang untuk membuat akta autentik dan memiliki kewenangan lainnya sebagaimana dimaksud dalam Undang-Undang ini atau berdasarkan undang-undang lainnya. Kadangkala pelabelan "terhormat" 
yang disandang Notaris di cederai oleh oknum-oknum Notaris yang tidak bertanggungjawab. Oknum tersebut tidak berpikir panjang akan akibat dari apa yang dilakukan. Teringat saat perkuliahan di kampus Magister Kenotariatan Fakultas Hukum Universitas Gadjah Mada (UGM) Yogyakarta, Penulis sering mendengar nasihat atau peringatan (warning) dari para dosen, "ketika kelak sudah berpraktek sebagai Notaris, jangan sekali-kali dalam menjalankan tugas dan tanggungjawab sebagai Notaris kita orientasinya uang, kalau kita melaksanakan jabatan dengan orientasi uang, maka kita pasti akan menabrak aturan yang ada. Kalau sudah seperti itu, maka cepat atau lambat kita akan bermasalah dengan hukum."

Nasihat atau peringatan (warning) diatas tidak muncul begitu saja, pasti ada sebab musabah kenapa para dosen Fakultas Hukum UGM memberi peringatan pada para mahasiswanya. Itu semata-mata dewasa ini banyak terjadi penyimpangan-penyimpangan yang dilakukan oleh oknum Notaris. Apa sebenarnya yang salah dengan oknum Notaris tersebut, apakah tatanan sosialnya bermasalah ataukah moral individunya yang tidak baik? Berkaitan dengan ini, Roberto M. Unger mengatakan bahwasannya kalau memang benar masalah tatanan sosial secara teori timbul dari situasi moral, maka masalah ini bisa diselesaikan dengan mengubah situasinya. Akan tetapi, perubahan yang mana yang mungkin, dan mana yang diperlukan? Berkaitan dengan pertanyaan diatas (bila dikaitkan dengan dunia Notaris), menurut Penulis semasa calon notaris masih sebagai mahasiswa Magister Kenotariatan perlu kiranya kita membentengi diri dengan moral yang baik, belajar dengan sungguh-sungguh mengenai seluk beluk dan semua kemelut tugas-tugas serta larangan notaris yang telah diatur dalam peraturan yang ada, agar kelak setelah mengemban amanah sebagai seorang Notaris tidak gegabah serta tepat menentukan formulasi yang pas untuk akta yang dibuatnya, dan yang terpenting dari itu adalah tidak mudah terpedaya oleh kenikmatan sesaat yang ujung-ujungnya membawa singgah di hotel prodeo (penjara). (Roberto M. Unger, 2010: 162)

\section{Metode Penelitian}

Metode penelitian yang digunakan Penulis dalam penelitian ini adalah penelitian yuridis-normatif dengan metode pendekatan konseptual dan pendekatan perundang-undangan. Data yang digunakan adalah data sekunder yang diperoleh melalui studi pustaka. Data yang terkumpul kemudian dianalasis dan disajikan secara deskriptif analitif. (Abdul Kadir Jaelani, I Gusti Ayu Ketut Rachmi Handayani, Lego Karjoko, 2019)

\section{Hasil dan Pembahasan}

\section{Pemalsuan Akta Autentik Sebagai Aspek Pidana}

Secara umum, Notaris tidak bisa di jatuhi hukum pidana terkait akta yang dibuatnya, apabila akta tersebut sudah dijalankan sebagaimana prosedur yang seharusnya, dalam hal ini yakni tidak bertentangan dengan peraturan perundang-undangan yang berlaku, moralitas agama, kesusilaan, atau ketertiban umum. Sebagai Notaris, harus berani mengatakan tidak pada penyelewengan aturan hukum bila ingin nyaman dan selalu aman dalam menjalankan profesinya, 
efek dari keberanian untuk menolak pertentangan itu, kedepannya dalam melaksanakan profesi tidak akan dihantui oleh rasa bersalah bahkan tidak akan ada ketakutan sewaktu-waktu bila berhadapan dengan prosesi hukum (gugatan hukum) berkaitan dengan jabatannya.

Hukum pidana adalah bagian dari hukum yang berlaku di suatu negara yang mengadakan dasar-dasar dan aturan-aturan untuk: (1) menentukan perbuatan-perbuatan yang tidak boleh dilakukan, yang dilarang, dengan disertai ancaman atau sanksi berupa pidana tertentu bagi barang siapa yang melanggar larangan tersebut; (2) menentukan kapan dan dalam hal apa kepada mereka yang melanggar larangan-larangan itu dapat dikenakan atau dijatuhi pidana sebagaimana yang telah diancamkan; (3) menentukan dengan cara bagaimana pengenaan pidana itu dapat dilaksanakan apabila orang yang disangka telah melanggar larangan tersebut. (Pipin Syarifin, 2008: 13-14)

Dasar-dasar pemidanaan yang bisa dilakukan terhadap Notaris, diantaranya: (1) Terdapat perbuatan yang dilarang/diharuskan oleh UndangUndang yang terkait dengan Hukum pidana (unsur obyektif); (2) Terdapat alat bukti yang cukup; (3) Terdapat kesalahan atau tidak ada alasan penghapus pidana; dan (4) Notaris tidak dibebani kewajiban untuk melakukan penyelidikan kebenaran materiil tentang apa yang dikemukan oleh para pihak, fungsi notaris mencatat/menulis apa-apa yang dikehendaki dan dikemukakan oleh para pihak yang mengahadap notaris (Putusan M.A No.702 K/Sip/1973 Tanggal 5 September 1973). (Sigit R., 2016) Salahsatu aspek pidana yang bisa disangkakan pada Notaris yang berkaitan dengan jabatannya adalah pemalsuan surat (akta) autentik. Agar tidak mudah di kriminalisasi, Notaris perlu membedakan Partij Akta dan Ambtelijke Akta.

Partij akta adalah akta yang dibuat oleh/dihadapan Notaris yang merupakan kehendak dari penghadap/para pihak sehingga isi dari akta tersebut merupakan tanggung jawab sepenuhnya dari penghadap/para penghadap/para pihak. Sedangkan Ambtelijke akta ialah akta yang dibuat oleh Notaris yang berisikan segala sesuatu yang didengar, dilihat, dialami oleh Notaris, untuk dituangkan ke dalam suatu akta. (Mulyoto, 2012: 9-10) Setelah ada kecakapan (kemampuan) membedakan hal tersebut diatas, seorang Notaris akan mampu memaknai secara tegas seperti apa dan bagaimana akibat hukum dari Partij Akta dan Ambtelijke Akta yang dimaksud.

Akta Autentik merupakan akta yang dibuat oleh atau dibuat dihadapan pejabat yang diberi wewenang oleh penguasa untuk membuatnya, menurut ketentuan-ketentuan yang telah ditetapkan undang-undang baik dengan ataupun tanpa bantuan yang berkepentingan untuk dicatat di dalamnya (M. Marwan dan Jimmy P., 2009: 30). Suatu akta otentik adalah suatu akta yang dibuat dalam bentuk yang ditentukan oleh Undang-Undang oleh atau di hadapan pejabat umum yang berwenang untuk itu di tempat akta itu dibuat. (Pasal 1868 KUHPerdata).

Akta autentik harus memenuhi apa yang dipersyaratkan dalam Pasal 1868 Kitab Undang-Undang Hukum Perdata (KUHPerdata), sifatnya kumulatif atau harus meliputi semuanya. Akta-akta yang dibuat, walaupun ditandatangani oleh 
para pihak, namun tidak memenuhi persyaratan Pasal 1868 KUHPerdata, tidak dapat diperlakukan sebagai akta autentik, hanya mempunyai kekuatan sebagai tulisan di bawah tangan (Pasal 1869 KUHPerdata) (Irma Devita Purnamasari, http://www.hukumonline.com, 03/03/2020). Oleh karenanya, mutlak harus diperhatikan apa yang tertuang dalam Pasal 1869 KUHPerdata biar derajat akta yang dibuat oleh seorang Notaris tidak turun nilai sakralnya dari akta notariill yang mempunyai kekuatan yang mengikat dan bisa dijadikan bukti otentik dihadapan pengadilan - menjadi akta di bawah tangan.

\section{Sanksi untuk Notaris dalam UUJN dan KUHP}

Pada UUJN Perubahan tidak ada pengaturan sanksi pidana yang dijatuhi pada Notaris. Rumusan Pasal 16 ayat (1) huruf b UUJN Perubahan, dalam menjalankan jabatannya, Notaris wajib membuat akta dalam bentuk minuta akta dan menyimpannya sebagai bagian dari Protokol Notaris. Penjelasan Pasal 16 ayat (1) huruf b UUJN Perubahan menggambarkan bahwa kewajiban ini dimaksudkan untuk menjaga keautentikan suatu akta dengan menyimpan akta dalam bentuk aslinya, sehingga apabila ada pemalsuan atau penyalahgunaan grosse, salinan, atau kutipannya dapat segera diketahui dengan mudah dengan mencocokkannya dengan aslinya. Pasal 16 ayat (11) huruf d UUJN Perubahan jo. Pasal 12 huruf d dan Penjelasan Pasal 12 huruf d UU Jabatan Notaris menyebutkan bahwa jika Notaris melanggar kewajiban tersebut, maka dapat dikatakan telah melakukan pelanggaran berat dan oleh karena itu dapat dikenai sanksi berupa pemberhentian dengan tidak hormat dari jabatannya oleh Menteri Hukum dan Hak Asasi Manusia atas usul Majelis Pengawas Pusat.

Ketiadaan pengaturan pidana dalam UUJN bukan berarti Notaris kebal terhadap sanksi pidana. Terkait ancaman pidana Notaris kita bisa temukan pada peraturan perundang-undangan lain, salahsatunya terkait pengaturan sanksi pidana pemalsuan surat (Akta) yang telah dibuat Notaris yang termuat pada Pasal 263 ayat 1 dan Pasal 264 ayat (1) Kitab Undang-Undang Hukum Pidana (KUHP). Pasal 263 ayat 1 KUHP berbunyi: Barang siapa membuat secara tidak benar atau memalsu surat yang dapat menimbulkan sesuatu hak, perikatan atau pembebasan hutang, atau yang diperuntukkan sebagai bukti dari sesuatu hal, dengan maksud untuk memakai atau menyuruh orang lain pakai surat tersebut seolah-olah isinya benar dan tidak dipalsu, diancam, jika pemakaian tersebut dapat menimbukan kerugian, karena pemalsuan surat, dengan pidana penjara paling lama enam tahun. Pasal 263 ayat 2 KUHP, diancam dengan pidana yang sama, barang siapa dengan sengaja memakai surat palsu atau yang dipalsukan seolah-olah sejati, jika pemakaian surat itu dapat menimbulkan kerugian. (Moeljatno, 2007: 96) lihat juga (Zaidah Nur Rosidah, Diana Zuhroh, Farhan \& Lego Karjoko,2018)

Unsur-unsur yang termuat dalam Pasal 263 ayat 1 KUHP diatas, diantaranya:

a. Dengan maksud untuk memakai atau menyuruh orang lain untuk memakai seolah-olah isinya benar atau tidak dipalsuan;

b. Perbuatan : Membuat Palsu atau memalsukan; 
c. Obyeknya :

(1) Surat yang dapat menimbulkan hak,

(2) Surat yang menimbulkan perikatan,

(3) Surat yang menimbulkan suatu pembebasan hutang,

(4) Surat yang dipergunakan sebagai bukti tentang sesuatu hal;

d. Atas pemakaian surat dapat menimbulkan kerugian;

e. Ancaman pidana paling lama 6 tahun.

Selain itu, Notaris juga dapat dijerat dengan ancaman Pasal 264 KUHP, terutama dalam ayat (1) Pasal 264 KUHP. Pemalsuan surat diancam dengan pidana penjara paling lama delapan tahun, jika dilakukan terhadap:

(1) Akta-akta otentik.

(2) surat hutang atau sertifikat hutang dari sesuatu negara atau bagiannya ataupun dari suatu lembaga umum;

(3) surat sero atau hutang atau sertifikat sero atau hutang dan suatu perkumpulan, yayasan, perseroan atau maskapai;

(4) talon, tanda bukti dividen atau bunga dari salah satu surat yang diterangkan dalam 2 dan 3, atau tanda bukti yang dikeluarkan sebagai pengganti surat-surat itu;

(5) surat kredit atau surat dagang yang diperuntukkan untuk diedarkan.

Berkaitan dengan Pasal 264 KUHP , R. Soesilo memberikan menjelaskan bahwa sudah barang tentu perbuatan yang diancam hukuman dalam pasal ini harus memuat segala elemen-elemen atau syarat-syarat yang termuat dalam Pasal 263 dan selain dari pada itu ditambah dengan syarat, bahwa surat yang dipalsukan itu terdiri dari surat authentik dsb. yang tersebut berturut-turut pada sub 1 s/d 5 dalam pasal ini, surat-surat mana bersifat umum dan harus tetap mendapat kepercayaan dari umum. Memalsukan surat semacam itu berarti membahayakan kepercayaan umum, sehingga menurut pasal ini diancam hukuman yang lebih berat dari pada pemalsuan surat biasa. (Lusia Savitri Diah Candrasari and Lego Karjoko,2018)

\section{Kasus Pemalsuan Akta Otentik}

Dari penelusuran Penulis, paling tidak ada beberapa contoh kasus pemalsuan akta otentik yang dibuat Notaris yang berkenaan dengan jabatannya sebagai pembuat akta autentik yang diperkarakan, diantaranya:

a. Pada 2010 di Kalimantan Timur (Kaltim) ada Notaris Khairu Subhan, S.H. yang kena kasus pemalsuan akta. Menurut Dirkrimum Polda Kaltim Kombes Pol Eka Yudha, Kasus ini masuk laporan pada Juli 2014. Pengakuan korban, mengalami kerugian mencapai Rp7 miliar karena akta Notaris tersebut. (Prokal, http://balikpapan.prokal.co, 03/03/2020)

b. Notaris Siti Masnuroh membuatkan akta terkait Yayasan Perguruan Wahidin. Di hadapan hakim tunggal Asiadi Sembiring, Siti Masnuroh yang berprofesi sebagai Notaris sejak 1999 ini mengaku Akta Nomor 77 dibuat pada 26 Agustus 2008 atas permintaan Poniman. Masnuroh 
mengakui bahwa saat itu hanya Poniman yang datang ke kantornya. Dalam akta notaris itu, ada enam lima orang lain yang ikut membubuhkan tanda tangan. Padahal aturan tegas menyebutkan, semua pihak harus menandatangani akta autentik di hadapan Notaris. (Fenomenanews, http://fenomenanews.com, 03/03/2020)

c. Kasus yang diputus Mahkamah Agung pada Putusan No. 1014 K/Pid/2013.

d. Kasus Putusan Pengadilan Negeri Lhokseumawe Nomor 40/Pid.B/2013/PN-LSM

Gambaran beberapa kasus diatas paling tidak menjadi contoh riil adanya pemalsual akta yang dilakukan oleh Notaris, selain kasus diatas, pasti masih banyak lagi kasus-kasus yang belum di ekspos media, dengan adanya peristiwa seperti yang di paparkan diatas, paling tidak seorang Notaris harus lebih berhatihati lagi dalam pembuatan akta, dengan adanya kehati-hatian akan meminimalisir gugatan perdata maupun pidana yang berkaitan dengan akta yang dibuatnya. (Lego Karjoko, Yulfitri Nurjanah, 2019)

Selain itu, Notaris dalam menjalankan tugas dan tanggungjawabnya, tidak perlu gentar dan takut bila berhadapan dengan hukum apabila prosedur pembuatan aktanya sudah sesuai dengan peraturan perundang undangan yang berlaku, karena pada dasarnya pembuatan akta Notaris yang didasarkan atas surat-surat yang tidak benar yang diajukan oleh para penghadap kepada Notaris, dimana Notaris tidak memeriksa kebenaran materiil, tidak membuat Notaris yang bersangkutan dikualifikasikan sebagai pelaku yang ikut serta dalam tindak pidana pemalsuan akta atentik. Eksistensi akta Notaris apabila surat yang diajukan oleh para penghadap terdapat cacat hukum yang nyata maka sepanjang tidak ada masalah, sepanjang tidak ada yang mempersoalkannya. Namun apabila ada pihak yang mempersoalkan dan menggugat di pengadilan, maka pengadilan dapat menjadikan dasar untuk membatalkannya atau setidaknya akta tersebut terdegradasi menjadi akta di bawah tangan. (I.G.N. Lego Karjoko, I Gusti Ayu Ketut Rachmi Handayani and Adi Sulistiyono, 2017)

\section{Penutup}

Berdasarkan uraian yang di paparkan di atas, maka kesimpulan yang dapat di ambil Penulis yakni Notaris sebenarnya tidak bisa di jatuhi hukum pidana terkait akta yang dibuatnya, apabila akta tersebut sudah dijalankan sebagaimana prosedur yang seharusnya, dalam hal ini yakni tidak bertentangan dengan peraturan perundang-undangan yang berlaku, moralitas agama, kesusilaan, atau ketertiban umum. Namun dewasa ini karena semakin banyaknya notaris dan juga semakin kompleksnya persoalan yang dihadapi oleh seorang Notaris maka ada juga Notaris yang bersentuhan dengan kasus hukum terkait pemalsuan akta yang dibuatnya, seperti kasus Notaris di Kaltim, akta terkait Yayasan Perguruan Wahidin, dan juga kasus putusan Mahkamah Agung No. $1014 \mathrm{~K} / \mathrm{Pid} / 2013$, Kasus Putusan Pengadilan Negeri Lhokseumawe Nomor 40/Pid.B/2013/PN-LSM yang telah juga Penulis sebutkan dalam uraian pembahasan diatas. Selain itu, Pasal 1 ayat (3) amandemen ketiga UUD 1945 menyebutkan bahwa Negara Indonesia 
adalah negara hukum. Karena Negara Indonesia menganut Negara hukum, maka dalam suatu negara hukum semua orang harus diperlakukan sama dihadapan hukum (equality before the law). Hal demikian juga tidak terkecuali pada profesi Notaris. Seorang notaris apabila melakukan pemalsuan akta Autentik, maka Notaris yang dimaksud dapat di pidana ababila memenuhi Unsur-unsur pidana yang termuat dalam Pasal 263 ayat 1 dan Pasal 264 ayat (1) KUHP.

\section{References}

Abdul Kadir Jaelani, I Gusti Ayu Ketut Rachmi Handayani, Lego Karjoko, "Executability of the Constitutional Court Decision Regarding Grace Period In The Formulation Of Legislation", International Journal of Advanced Science and Technology Vol. 28, No. 15, (2019).

Lego Karjoko, I Gusti Ayu Ketut Rachmi Handayani and Adi Sulistiyono, "Setting of Plantation Land Area Limitation Based on Social Function Principles of Land Cultivation Rights to Realize Social Welfare-Promoting Plantation, Jurnal Dinamika Hukum, Volume 17 No 1 (2017)

Lego Karjoko, Yulfitri Nurjanah, "The Legality of Freehold Title and Legal Implications Against of Land Makers Officers (The Study of Freehold Title Issuance Number 1576/Nusukan Village, Banjarsari Sub-District, Surakarta City, Central Java)", International Journal of Scientific and Technology Research 8(10), 2019.

Lusia Savitri Diah Candrasari and Lego Karjoko, "Principle of Social Function of Land Cultivation Right in Agritourism Accommodation in Indonesia", International Journal of Multicultural and Multireligious Understanding, Vol. 5, No. 2, April 2018.

Zaidah Nur Rosidah, Diana Zuhroh, Farhan \& Lego Karjoko, "Justiceaspect Ofthe Settlement Dispute Insharia Business Through The Religious Court", South East Asia Journal of Contemporary Business, Economics and Law, Vol. 12, Issue 4 (2017)

Atmasasmita, Romli. (2011). Sistem Peradilan Pidana Kontemporer. Jakarta: Kencana.

Moeljatno. (2007). KUHP (Kitab Undang-Undang Hukum Pidana). Cet. Ke-20. Jakarta: PT. Bumi Aksara.

Marwan, M. dan Jimmy P. (2009). Kamus Hukum (Dictionary of Law Complete Edition). Surabaya: Reality Publisher.

Mulyoto. (2012). Perjanjian: Teknik, Cara Membuat, dan Hukum Perjanjian yang Harus Dikuasai. Yogyakarta: Cakrawala Media.

Soesilo, R., (1991). Kitab Undang-Undang Hukum Pidana (KUHP): Serta Komentar-Komentarnya Lengkap Pasal Demi Pasal, Kota Bogor: Politeia.

Syarifin, Pipin. (2008). Hukum Pidana di Indonesia. Cet.ke-2. Bandung: Pustaka Setia.

Unger, Roberto M. (2010). Teori Hukum Kritis: Posisi Hukum dalam Masyarakat Modern. Cet. Ke4. alih bahasa Dariyatno dan Derta Sri Widowatie. Bandung: Nusa Media.

M., I.G.N. Wisnu Herbi. "Tindak Pidana Pemalsuan Akta Otentik yang Turut Serta Dilakukan oleh Notaris". Tesis Program Studi Magister Kenotariatan Fakultas Hukum Universitas Narotama Surabaya. 2016. 